\title{
PENERAPAN TEKNOLOGI TEPAT GUNA DALAM PENGENDALIAN ORGANISME PENGGANGGU TANAMAN DAN PENANGANAN PASCA PANEN PADI DI DESA TEBAS SUNGAI
}

\author{
Daud Perdana ${ }^{1}$, Hamdi ${ }^{2}$, Winda Apriani ${ }^{3}$ \\ ${ }^{1}$ Politeknik Negeri Sambas, Jalan Raya Sejangkung Desa Sebayan Kabupaten Sambas \\ ${ }^{2}$ Politeknik Negeri Sambas, Jalan Raya Sejangkung Desa Sebayan Kabupaten Sambas \\ ${ }^{3}$ Politeknik Negeri Sambas, Jalan Raya Sejangkung Desa Sebayan Kabupaten Sambas \\ 1'daudp3rdan@gmail.com
}

\begin{abstract}
ABSTRAK
Kabupaten Sambas merupakan salah satu sentra utama produksi padi di Kalimantan Barat. Kabupaten ini berada di wilayah perbatasan antara Indonesia dan Malaysia. Desa Tebas Sungai merupakan satu diantara sentra padi yang pernah gagal panen diakibatkan serangan tikus pertanian pada bulan Juli 2016. Mitra kegiatan Penerapan Penerapan Teknologi Tepat Guna kepada Masyarakat ini adalah Kelompok Tani Candra Mekar dan Sari Melati Kencana yang berada di Desa Tebas Sungai Kecamatan Tebas Kabupaten Sambas. Kelompok ini relatif tertinggal dibanding kelompok tani lainnya di kecamatan disebabkan kurangnya bantuan di bidang pertanian. Persoalan yang dihadapi mitra secara umum adalah serangan hama tikus, serangan hama wereng coklat, penggerek batang, lembing batu, tungro, blas, dan hawar, kurang jumlah dan efektifnya penggunaan mesin perontok padi, ketersediaan pupuk subsidi yang sangat terbatas, dan irigasi belum bisa dilakukan dengan baik akibat terbatasnya pompa. Solusi yang disepakati dari permasalahan prioritas mitra adalah pengendalian tikus pertanian, pengendalian hama serangga menggunakan perangkap serangga (light trap), serta pembuatan dan pengelolaan mesin perontok padi untuk penanganan pasca panen.

Target luaran kegiatan ini antara lain: 1) Program pengendalian tikus pertanian menghasilkan luaran alat perangkap tikus pertanian berjumlah 10 set, terselesaikan 10 set; 2) Program pengendalian hama serangga menggunakan perangkap serangga menghasilkan luaran 10 set, sudah tercapai 10 set; dan 3) Program pembuatan dan pengelolaan mesin perontok padi menghasilkan luaran mesin perontok padi sebanyak 2 unit, terealisasi 2 unit; 4) Publikasi pada jurnal berISSN DIPAMAS; dan 5) Publikasi kegiatan pada media massa (online 1 kali terealisasi 4 kali, CSMTV 1 kali sudah terealisasi dan telah diupload pula di youtube.com, dan surat kabar/media massa realisasi 2 kali versi cetak).

Kegiatan PPTTG ini melalui tahapan-tahapan: 1) Program pengendalian tikus pertanian; 2) Program pengendalian hama serangga; dan 3) Program pembuatan dan pengelolaan mesin perontok padi.

Secara ekonomi, adanya penerapan teknologi melalui PPTTG akan mencegah kerugian dalam usahatani padi (akibat serangan tikus sawah), mengefektifkan pencegahan serangan hama (melalui perangkap hama/light trap), dan mengefisienkan biaya pasca panen padi (dengan alat perontok padi). Secara keseluruhan dampak ekonominya dapat menyebabkan peningkatan pendapatan petani padi sawah sehingga diharapkan mampu mensejahterakan ekonomi masyarakat tani. Secara sosial, dampak yang didapat dari penerapan teknologi adalah adanya ketenteraman di masyarakat karena adanya alat yang mencegah terjadinya kerugian dalam pengusahaan budidaya tanaman padi, serangan hama maupun penyakit yang dibawa oleh hama, dan tidak lagi terjadi rebutan antrian terhadap mesin perontok padi karena telah ada alat yang diberikan kepada kelompok.
\end{abstract}

Kata kunci: hama, padi, perangkap serangga 


\section{PENDAHULUAN}

\subsection{Analisis Situasi}

Kabupaten Sambas merupakan salah satu sentra utama produksi padi di Kalimantan Barat. Kabupaten ini berada di wilayah perbatasan antara Indonesia dan Malaysia. Kabupaten Sambas merupakan lumbung padi Kalimantan Barat. Tidak heran jika "gelar" tersebut memberi konsekuensi kepada pemerintah daerah untuk lebih memacu produktivitas hasil padi. Produktivitas padi yang dihasilkan tahun 2017 dengan luas panen padi sebesar 74,03 ribu hektar yang terdiri dari 3,81 ribu hektar merupakan luas panen tanaman padi ladang dan sebesar 70,22 ribu hektar merupakan luas panen tanaman padi sawah (BPS, 2018). Dengan kata lain, produksi padi Kabupaten Sambas mencapai 102.000 114.300 ton pertahun. Untuk meningkatkan produktivitas padi, pemerintah daerah akan membangun dan memperbaiki jaringan irigasi, optimalisasi lahan, gerakan pengelolaan tanaman terpadu, penyediaan alsintan traktor dan pompa air serta pengawalan dan pendampingan bersama TNI AD mendukung ketahanan pangan. Kegiatan tersebut bertujuan mempercepat sawasembada pangan baik di tingkat lokal maupun nasional.

Kecamatan Tebas merupakan wilayah di Kabupaten Sambas, memiliki produktivitas yang relatif tinggi. Budidaya tanaman padi di Kecamatan Tebas hampir seluruhnya menggunakan benih unggul. Kelompok tani di wilayah Kecamatan Tebas menanam padi dua kali dalam setahun. Jenis padi yang ditanam adalah padi unggul dengan umur 130-135 hari setelah tanam. Beberapa jenis padi unggul yang ditanam dintaranya Cilosari, Cisokan, Situbagendit, Inpara dan Inpari. Jenis padi unggul tersebut, memiliki hasil produksi yang besar di setiap wilayah desa di Kecamatan Tebas. Beberapa diantaranya yang tertinggi adalah di Desa Tebas Sungai. Saat ini Desa Tebas sungai memiliki 16 kelompok tani yang tergolong dalam satu Gapoktan bernama Mekar Bersatu.

Di Desa Tebas Sungai potensi hasil padi menghasilkan rata-rata 5-7 ton per hektar (ratarata produktivitas tanaman padi di Kabupaten Sambas adalah 3 ton/ha). Dalam memproduksi padi unggul, mayoritas petani telah menerapkan pengelolaan tanaman terpadu dengan menggunakan sistem tanam jajar legowo. Sistem tanam jajar legowo yang diterapkan petani cenderung menggunakan sistem $4: 1$, yaitu empat baris tanaman dan 1 kosong. Sistem ini memudahkan dalam pemupukan dan perawatan tanaman. Sistem tersebut memberikan hasil produksi yang cenderung tinggi. Dengan sistem jajar legowo, hasil tersebut memberikan andil besar dalam peningkatan produksi padi di Kecamatan Tebas pada umumnya.

Produksi dalam usahatani padi yang dijalankan petani pada Desa Tebas Sungai, diawali dengan persiapan lahan dengan cara ditraktor. Cara tersebut lebih maju dibanding wilayah lainnya. Pengolahan lahan dengan traktor memberikan hasil produksi yang tinggi. Kontribusi tersebut tidak terlepas dari peran kelompok tani. Kelompok tani selain kelembagaan ekonomi petani juga wadah kerjasama yang berfungsi sebagai unit produksi. Kelompok tani dalam konsepsi Departemen Pertanian (1997) berfungsi sebagai unit belajar, unit kerjasama, dan unit produksi. Selain itu, kelompok tani juga dapat diarahkan menjadi suatu unit usaha. Kelompok tani di Desa Tebas Sungai yang telah menjadikan usahatani padi menjadi sebuah unit usaha diantaranya kelompok tani Candra Mekar dan Sari Melati Kencana. Kedua kelompok tani tersebut memiliki hamparan sawah seluas $50 \mathrm{Ha}$, sehingga manajemen dalam pola tanam telah diatur melalui kelompok tani.

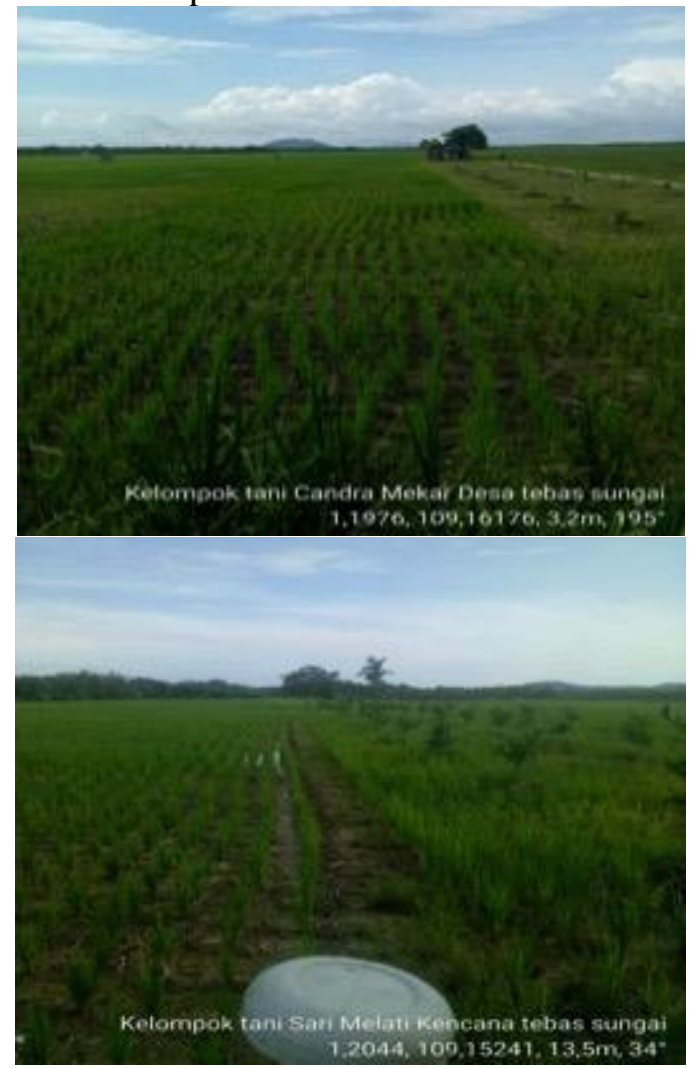

Gambar 1. Lahan pertanian milik kelompok tani Candra Mekar dan Sari melati Kencana

Pola tanam padi yang berlaku adalah musim tanam rendengan dan musim tanam gadu. Musim tanam rendengan diawali bulan September sampai dengan bulan Februari. 
Sedangkan musim tanam gadu diawali bulan Maret sampai dengan bulan Agustus. Musim tanam rendengan umumnya diawali musim hujan tiba. Sedangkan musim tanam gadu diawali ketika musim hujan berakhir atau memasuki musim kemarau. Manajemen pola tanam yang telah diterapkan pada kelompok tani Candra Mekar dan Sari Melati Kencana di Desa Tebas Sungai telah berhasil merubah sikap petani untuk selalu menanam padi dua kali dalam setahun. Selain pola tanam, manajemen usahatani yang dimiliki kelompok tani Candra Mekar dan Sari Melati Kencana yaitu mampu mengatur kebutuhan akan pupuk selama musim tanam. Kemampuan dalam manajemen pupuk mereka tuangkan dalam penyusunan rencana definitif kebutuhan kelompok (RDKK). Dokumen RDKK menjadi penilaian penyuluh dan Dinas Pertanian dalam menyalurkan pupuk pada kelompok tani.

Kebutuhan pupuk pada kelompok tani merupakan jumlah total dari kebutuhan pupuk anggota kelompok tani. Beberapa jenis pupuk yang disalurkan untuk produksi padi adalah urea, SP36, dan KCl. Kebutuhan pupuk setiap

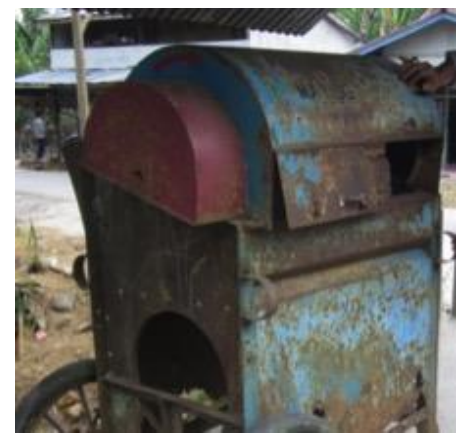

hektarnya adalah urea $150 \mathrm{~kg}$, SP36 $100 \mathrm{~kg}, \mathrm{KCL}$ $75 \mathrm{~kg}$. Jumlah tersebut umumnya dapat berkurang disebabkan penggunaan pupuk organik yang berimbang. Ketika pengolahan lahan, pupuk organik digunakan sebagai pupuk dasar. Sehingga jumlah pupuk kimia seperti urea, SP36 dan KCL dapat ditekan. Manajemen usahatani padi yang dimiliki kelompok tani selalu dibina melalui kegiatan penyuluhan pertanian. Kegiatan penyuluhan yang dilaksanakan melalui pendekatan kelompok. Seorang penyuluh dalam menjalankan fungsinya sebagai fasilitator selalu mengadakan kegiatan pada kelompok tani.

Kegiatan penyuluhan yang dilakukan di

Desa Tebas Sungai terbatas pada pengetahuan teknis budidaya. Pengetahuan tersebut berupa pengolahan lahan sampai dengan panen. Kegiatan teknis yang dilakukan merupakan satu kesatuan antara manajemen produksi usahatani dengan manajemen administrasi pada kelompok tani. Sehingga unit produksi dan manajemen telah dikoordinir oleh kelompok melalui pengurus. Koordinasi dalam produksi mampu mereka jalankan sesuai kesepakatan bersama. Namun upaya peningkatan produksi yang dilakukan kelompok tani belum diikuti oleh manajemen pengendalian hama penyakit padi. Pengetahuan tersebut hanya dimiliki sebagian petani saja ketika berinteraksi melalui petugas pengamat organisnisme pengganggu tanaman (OPT). Akibatnya pengetahuan yang dimiliki petani tentang pengendalian hama padi tidak terintegrasi bersama manajemen usahatani yang telah dijalankan. Beberapa serangan organisme pengganggu tanaman padi selalu menjadi masalah utama dalam peningkatan produksi, mulai dari persemaian, pemeliharaan dan masa panen. Hama dan penyakit yang biasa merusak tanaman padi adalah tikus, wereng coklat, penggerek batang, lembing batu, penyakit tungro, blas, dan hawar daun bakteri, dan berbagai penyakit yang disebabkan oleh cendawan. Kondisi yang demikian dapat menurunkan produksi padi lebih dari 30\%. Pada Juli 2016, di Desa Tebas Sungai gagal panen akibat serangan hama tikus.

Masalah lainnya dalam kegiatan produksi padi di desa Tebas Sungai adalah: ratarata padi yang dihasilkan oleh para petani untuk tiap kali musim panen \pm 5-7 ton / Ha. Proses perontokan padi setelah dipanen dilakukan dengan menggunakan mesin perontok padi (Power Thresher). Di desa Tebas Sungai hanya terdapat 2 unit mesin perontok padi yang merupakan bantuan dari Dinas Pertanian Kabupaten Sambas tahun 1998 dan tahun 2004. Keberadaan 2 unit mesin perontok padi bagi anggota kelompok tani di desa Tebas Sungai sangat membantu, karena dengan adanya 2 unit mesin, proses merontok padi menjadi sangat cepat. Namun sejak tahun 2011, 1 dari 2 unit mesin peronrok padi yang dimiliki kelompok tani sudah tidak layak untuk digunakan karena bodinya sudah keropos dan berkarat. Dengan demikian proses perontokan padi petani menjadi lambat, bahkan ada petani yang harus merontok padi dengan cara manual yaitu dengan menginjak-injak padi sampai rontok. Cara ini tentu memerlukan waktu yang cukup lama.

\section{Gambar 2. Mesin perontok di Desa Tebas} Sungai

Persoalan-persoalan yang dihadapi di Kelompok Tani Candra Mekar dan Sari Melati Kencana adalah sebagai berikut:

1. Serangan hama tikus yang bisa menggagalkan panen seperti yang terjadi di bulan Juli 2016 dan ancaman serangan di setiap musim tanam.

2. Serangan hama wereng coklat, penggerek batang, lembing batu, penyakit tungro, blas, 
dan hawar daun bakteri yang mengancam keberhasilan budidaya tanaman padi.

3. Mesin perontok padi untuk penanganan pasca panen tersedia 2 unit dan kurang berfungsi dengan baik. Posisi desa yang harus menyeberang sungai untuk mengakses desa lainnya jika ingin meminjam atau menyewa dari desa lain menghadapi kendala transportasi sehingga tidak dilakukan masyarakat sehingga menggunakan sumber daya yang ada. Dengan kondisi mesin perontok yang sangat terbatas, penggunaannya dengan antri dan menjadi permasalahan sosial, sehingga sering ditemukan terjadi pertengkaran sesama petani karena setiap orang ingin segera menggunakannnya.

4. Ketersediaan pupuk subsidi yang sangat terbatas menyebabkan kendala dalam pemumpukan dengan harga terjangkau.

5. Permasalahan pengairan/irigasi di masa kemarau tidak bisa dikendalikan karena belum ada irigasi sehingga dalam keadaan darurat ini menggunakan pompanisasi. Pompa yang tersedia hanya satu unit dan dengan kapasitas kecil untuk lahan 50 hektar. Instalasi pipa juga tidak ada.

\subsection{Permasalahan Mitra}

Mengacu kepada butir Analisis Situasi, permasalahan mitra yang menjadi prioritas untuk ditangani dalam kegiatan PPTTG mencakup halhal berikut ini.

1. Serangan hama tikus yang bisa menggagalkan panen seperti yang terjadi di bulan Juli 2016 dan ancaman serangan di setiap musim tanam.

Persoalan ini akan segera ditangani dengan alasan berikut. Peningkatan produksi yang dilakukan kelompok tani belum diikuti oleh manajemen pengendalian hama penyakit padi. Akibatnya pengetahuan yang dimiliki petani tentang pengendalian hama padi tidak terintegrasi bersama manajemen usahatani yang telah dijalankan. Beberapa serangan organisme pengganggu tanaman padi selalu menjadi masalah utama dalam peningkatan produksi. Kondisi yang demikian dapat menurunkan produksi padi lebih dari $30 \%$. Serangan hama tikus bisa mengancam sepanjang musim bahkan sepanjang tahun jika pertanaman dilakukan tidak serempak. Apalagi sejarahnya di daerah Desa Tebas Sungai dulu tanam padi setahun sekali sehingga populasi tikus tidak berkembang cepat seperti saat ini. Pembekalan pengetahuan ini penting tersampaikan sampai pada tataran teknis agar setiap anggota dalam kelompok tani mengetahui dan menjalankannya secara bersama-sama agar perkembangbiakan tikus dalam ditekan.

2. Serangan hama wereng coklat, penggerek batang, lembing batu, penyakit tungro, blas, dan hawar daun bakteri yang mengancam keberhasilan budidaya tanaman padi.

Pengetahuan petani yang kurang dalam pengendalian hama penyakit menyebabkan penanganan yang sering tidak tepat sehingga perlu adanya beberapa cara untuk menanganinya baik dilakukan dengan alat maupun dengan aplikasi pestisida tertentu di bawah kendali penyuluh pertanian yang ada pada dinas terkait. Masalah ini sangat urgen untuk segera ditangani karena jika dibiarkan atau salah penanganan akan menyebabkan kekurangan hasil produksi atau mengancam sampai pada titik gagal panen.

3. Mesin perontok padi untuk penanganan pasca panen tersedia 2 unit dan kurang berfungsi dengan baik. Posisi desa yang harus menyeberang sungai untuk mengakses desa lainnya jika ingin meminjam atau menyewa dari desa lain menghadapi kendala transportasi sehingga tidak dilakukan masyarakat sehingga menggunakan sumber daya yang ada.

Melihat kondisi mesin perontok padi yang ada di desa Tebas Sungai, terdapat 1 unit mesin perontok padi yang sudah tidak layak untuk dipergunakan karena bodinya sudah keropos dan berkarat. Kondisi ini mengakibatkan petani harus mengandalkan 1 unit mesin untuk merontok padi sehingga petani harus menunggu antri yang cukup lama untuk mendapatkan giliran merontok, bahkan ada petani yang harus merontok padi dengan cara manual yaitu dengan cara menginjak-injak padi sampai rontok. Cara ini tentu memerlukan waktu yang cukup lama. 


\section{TUJUAN DAN SASARAN}

\subsection{Tujuan}

berikut:

Tujuan kegiatan PPTTG adalah sebagai

1. Pengendalian tikus pertanian

Solusi ini untuk menyelesaikan masalahmasalah sebagaimana dijelaskan pada Bab 1 . Dengan melakukan pembuatan, pemasangan dan pengelolaan perangkap tikus pertanian yang disertai pula dengan pembekalan ilmu dan pengetahuan dalam pengelolaan usahatani secara baik diharapkan mampu mengendalikan serangan tikus sawah/pertanian dan mampu mencegah kehilangan hasil $30 \%$ atau kegagalan panen.

2. Pengendalian hama serangga menggunakan perangkap serangga (light trap)

Pada item ini, disertai pula dengan pembekalan ilmu untuk mengenal dan mengendalikan hama dan penyakit secara komprehensif serta memanfaatkan perangkap serangga untuk tanaman padi dan tanaman lainnya di lahan yang dikelola oleh petani yang tergabung dalam 2 kelompok tani dalam luasan lahan 50 hektar tersebut.

3. Pembuatan dan pengelolaan mesin perontok padi untuk penanganan pasca panen

Membuat dan menghibahkan mesin perontok padi kepada masyarakat ini akan mampu mencegah rebutan/antrian panjang dan pertikaian dalam merebutkan mesin yang terjadi selama ini. Kegiatan ini pula bisa membekali mereka untuk menggunakan mesin dengan baik agar lebih awet dan tahan lama serta bisa memperbaikinya jika terjadi kerusakan ringan.

\subsection{Sasaran}

Sasaran yang dihasilkan dari masingmasing kegiatan PPTTG adalah sebagai berikut:

1. Program pengendalian tikus pertanian menghasilkan luaran alat perangkap tikus pertanian berjumlah 10 set.

Untuk menghasilkan luaran alat perangkap tikus pertanian dan penggunaannya secara terus menerus (berkelanjutan), maka kegiatan-kegiatan pendukungnya adalah:

a. Pembuatan alat perangkap tikus pertanian

b. Instalasi alat perangkap tikus pertanian

c. Pelatihan pemakaian dan perawatan alat perangkap tikus

d. Pendampingan operasional

e. Pelatihan manajemen usahatani tanaman padi

2. Program Pengendalian hama serangga menggunakan perangkap serangga (light trap) menghasilkan luaran alat perangkap serangga sebanyak 10 set.

Perangkap serangga dapat mengetahui organisme pengganggu tanaman seluas 50 hektar. Cara kerja perangkap serangga bekerja setiap malam. Cahaya lampu pada perangkap merupakan sumber energi serangga ketika malam. Serangga akan mendekati cahaya lampu yang akhirnya akan jatuh di bawah lampu. Jumlah serangga dapat dihitung dengan cara memisahkan serangga hama dan serangga musuh alami. Ketika serangga hama lebih banyak dibanding serangga musuh alami, maka ledakan hama pada tanaman padi akan terjadi. Kegiatankegiatan pendukung untuk menghasilkan luarannya antara lain:

a. Pelatihan pengenalan dan pengendalian hama dan penyakit tanaman padi

b. Pembuatan alat perangkap serangga

c. Instalasi alat perangkap serangga

d. Pelatihan pemakaian dan perawatan alat perangkap serangga

3. Program pembuatan dan pengelolaan mesin perontok padi menghasilkan luaran mesin perontok padi sebanyak 2 unit.

Dalam mencapai luaran mesin perontok padi, kegiatan-kegiatan pendukungnya antara lain sebagai berikut:

a. Pembuatan mesin perontok padi

b. Uji operasi mesin perontok padi

c. Pelatihan pengoperasian dan perawatan mesin perontok padi

4. Publikasi di pada jurnal ber-ISSN DIPAMAS yang diterbitkan oleh Politeknik Negeri Sambas sebanyak satu artikel

5. Publikasi kegiatan pada media massa (online 1 kali, CSMTV 1 kali, dan surat kabar 1 kali)

\section{METODE PELAKSANAAN}

\subsection{Pihak Yang Terlibat dalam Kegiatan Penerapan TTG}

Kegiatan Program Penerapan Teknologi tepat guna kepada masyarakat akan dilakukan dengan melibatkan pengurus kelompok tani Candra Mekar dan Sari Melati Kencana yang berada di Desa Tebas Sungai, Kecamatan Tebas. Kegiatan akan memfokuskan pada pembuatan perangkap serangga dan perangkap tikus untuk ditempatkan di hamparan sawah. Selain itu kegiatan penyuluhan berupa cara identifikasi serangga hama dan teknis perawatan/pemeliharaan perangkap serangga dan perangkap tikus yang ada di hamparan sawah. Peserta pelatihan maupun kegiatan di lokasi/lahan pertanian melibatkan semua anggota 
kelompok tani. Dalam pelatihan pengenalan dan pengendalian hama dan penyakit juga melibatkan PPL Kecamatan Tebas. Dalam implementasi kegiatan PPTTG, tim juga telah melibatkan semua ketua kelompok tani se-Kecamatan Tebas berdasarkan permintaan dari PPL Kecamatan Tebas dan gabungan kelompok tani yang ada di Kecamatan Tebas.

\subsection{Metode Penerapan TTG}

Metode penerapan TTG ini dilakukan dengan identifikasi kebutuhan masyarakat (sudah dilakukan sebelum pembuatan proposal), pembuatan alat, instalasi, uji operasi, pendampingan operasional, dan pelatihan.

\subsection{Tahapan Penerapan TTG Kepada Masyarakat}

3.3.1. Program pengendalian tikus pertanian diterapkan dengan tahapan sebagai berikut:

- Pembuatan alat perangkap tikus pertanian, yang dilaksanakan di Politeknik Negeri Sambas.

- Instalasi alat perangkap tikus pertanian bersama pengurus kelompok di Desa Tebas Sungai yang dilakukan di lahan sawah.

- Pelatihan pemakaian dan perawatan alat perangkap tikus dilaksanakan di Desa Tebas Sungai antara tim pelaksana kegiatan dengan peserta semua anggota kelompok tani dan masyarakat lainnya di sekitar Desa Tebas Sungai yang berminat.

- Pendampingan operasional penggunaan alat perangkap tikus dan alat perangkap serangga dilaksanakan secara bersamaan di sawah kelompok tani.

- Pelatihan manajemen usahatani tanaman padi dilaksanakan di rumah warga pengurus atau anggota kelompok tani.

3.3.2. Program pengendalian hama serangga diterapkan dengan tahapan sebagai berikut:

- Pelatihan pengenalan dan pengendalian hama dan penyakit tanaman padi di rumah warga anggota kelompok tani yang melibatkan PPL Kecamatan Tebas.

- Pembuatan alat perangkap serangga dilaksanakan oleh tim pelaksana kegiatan di Politeknik Negeri Sambas.
- Instalasi alat perangkap serangga dilaksanakan di Desa Tebas Sungai antara tim pelaksana dengan pengurus kelompok tani.

- Pelatihan pemakaian dan perawatan alat perangkap serangga di rumah warga pengurus atau anggota kelompok tani.

3.3.3. Program pembuatan dan pengelolaan mesin perontok padi diterapkan dengan tahapan sebagai berikut:

- Pembuatan mesin perontok padi dilaksanakan tim pelaksana kegiatan di Politeknik Negeri Sambas.

- Uji operasi mesin perontok padi dilaksanakan di Desa Tebas Sungai bersama semua anggota kelompok tani.

- Pelatihan pengoperasian dan perawatan mesin perontok padi dilaksanakan di rumah warga masyarakat anggota kelompok tani.

\subsection{Deskripsi TTG yang Diterapkan}

3.4.1. Perangkap serangga (light trap)

Cara kerjanya, energi listrik bersumber dari tenaga surya $(\mathrm{A})$ disimpan ke dalam baterai (B) digunakan untuk menghidupkan lampu (C), perangkap serangga bekerja setiap malam. Cahaya lampu pada perangkap merupakan sumber energi serangga ketika malam. Serangga akan mendekati cahaya lampu yang akhirnya akan jatuh di bawah lampu dan masuk ke dalam Box Penampung Hama yang telah diberi bak berisi air sabun. Alat perangkap serangga dapat dilihat pada Gambar 1.

\subsubsection{Perangkap Tikus Pertanian}

Alat ini dipasang di lokasi yang banyak tikus. Alat ini berfungsi sebagai benteng tanaman (Kebun/Sawah), mampu membasmi tikus secara terus menerus.

\section{Keterangan:}
a. Panel Surya
b. Box Bateray
c. Lampu LED
d. Box Penampung hama
e. Pondasi Beton
f. Kayu Cerucuk 


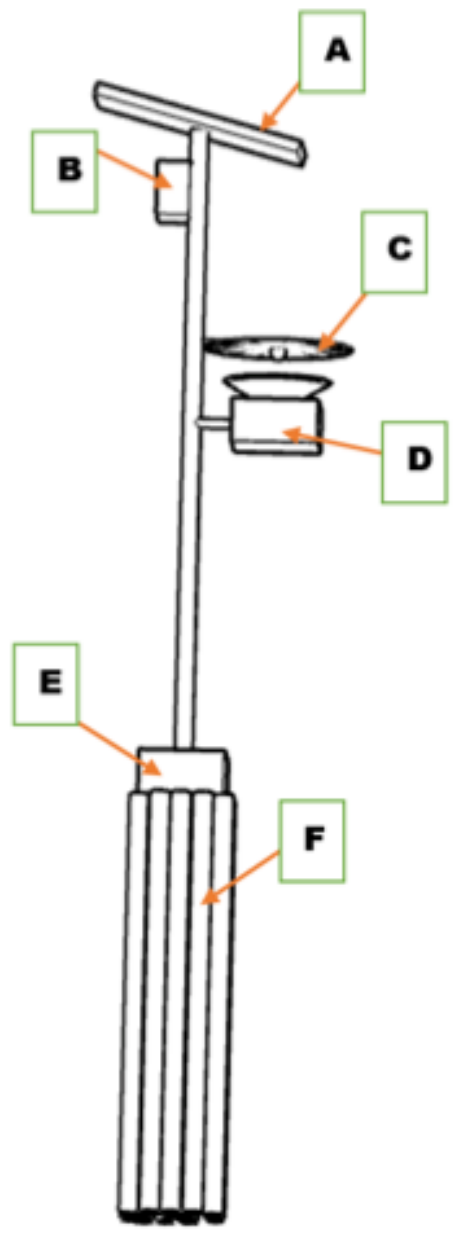

Gambar 1. Perangkap serangga

\subsubsection{Mesin perontok padi (thresher)}

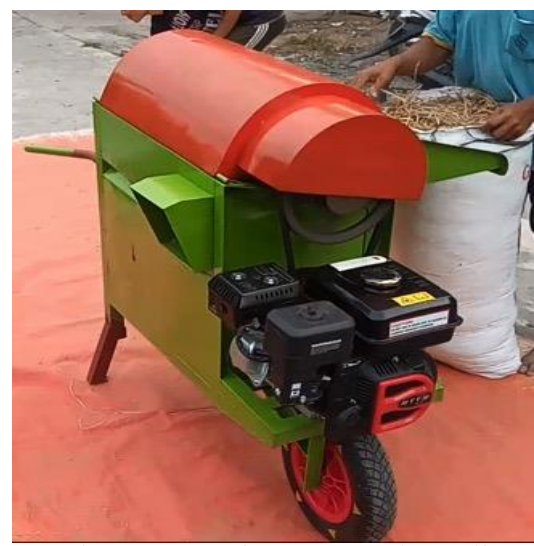

Gambar 3. Mesin perontok padi

\section{Spesifikasi mesin:}

- Kapasitas Gabah : 500 kg / jam

- Dimensi Mesin
a. Panjang $=67 \mathrm{Cm}$
b. Lebar $=43 \mathrm{Cm}$
c. Tinggi $=80 \mathrm{~cm}$

Mesin perontok padi (thresher) adalah mesin yang digunakan untuk memisahkan biji padi dari tangkainya. Dalam usaha tani padi, thresher merupakan alat untuk merontokkan padi menjadi gabah. Alat ini merupakan alat bantu bagi tenaga kerja untuk memisahkan gabah dengan jeraminya, sehingga penggunaan mesin perontok padi (thresher) menjadi satu kesatuan dengan tenaga kerja saat panen. Mesin Thresher adalah jenis mesin perontok yang telah terbukti handal dan sangat cocok dengan berbagai jenis lahan persawahan di Indonesia. Pada umumnya ukuran mesin perontok padi yang sudah ada dibuat dengan ukuran dan kapasitas besar yang digerakan dengan motor bertenaga diesel, sehingga terasa sangat berat untuk dioperaikan dan dibawa ke sawah yang jaraknya cukup jauh dari pemukiman dan jalan umum, hal ini sangat menyulitkan sehingga petani harus mengangkut padi kotornya (padi dan tangkainya) terlebih dahulu untuk dibawa ke tempat perontokan. Hal seperti ini sering terjadi dan merupakan masalah bagi para petani. Selain itu harga untuk sebuah mesin perontok padi (thresher) di pasaran terasa sangat mahal, sehingga untuk kalangan petani menengah ke bawah tidak mampu untuk membelinya dan selalu mengharapkan bantuan dari pemerintah.

Dalam disain ini mesin perontok padi dibuat dengan ukuran kecil, dengan cara memodifikasi bentuk dan ukuran mesin yang sudah ada, dengan konstruksi yang sederhana. Mesin ini terbuat dari bahan logam besi yang ringan, tanpa mengurangi kwalitas bahan, biaya pembuatan mesin ini pun dapat lebih murah sehingga harga mesin dapat terjangkau oleh kalangan petani. Untuk memudahkan pada saat dibawa ke lapangan, mesin ini dilengkapi roda sehingga hanya membutuhkan satu orang operator saja. Agar mudah dalam pengoperasiannya mesin ini dirancang dengan penggerak motor bensin daya $5.5 \mathrm{hp}$, selain perawatan dan suku cadangnya murah bahan bakar yang digunakan juga mudah didapat. Dengan ini diharapkan dapat mengatasi keluhan para petani dalam proses merontok hasil panennya, sehingga dapat meningkatkan hasil produksi dan menambah penghasilan para petani.

\subsection{Prosedur Kerja untuk Mendukung Realisasi Metode}

Prosedur kerja untuk mendukung realisasi metode adalah sebagai berikut:

1. Pelaksanaan kegiatan dimulai dengan sosialisasi kepada pengurus kelompok tani jika proposal disetujui secara resmi dan kontrak kerja telah ditandatangani oleh ketua pelaksana.

2. Pelaksanaan kegiatan diusahakan tidak mengganggu jadwal tanam atau kegiatan pertanian dari anggota kelompok tani. 
3. Kegiatan dilaksanakan menyesuaikan jadwal dan mendukung tercapainya luaran sesuai yang direncanakan.

4. Kegiatan pada mitra 1 dan mitra 2 dibuat terpisah untuk efektivitas (bukan efisiensi) kegiatan.

5. Kegiatan pembuatan alat sudah mulai dilaksanakan di awal masa kontrak.

6. Kegiatan-kegiatan pendukung tercapainya luaran dilaksanakan bisa di masa-masa pertengahan atau sedang pembuatan alat.

\subsection{Partisipasi Mitra dalam Pelaksanaan Program}

Dalam kegiatan ini, partisipasi mitra dalam pelaksanaan kegiatan antara lain:

1. Memberikan masukan dan saran kepada tim pelaksana kegiatan dalam rangka memberikan solusi teknis saat pelaksanaan kegiatan.

2. Menyediakan tempat/lokasi pemasangan perangkap hama dan tikus.

3. Membantu tim pelaksana kegiatan dalam membangun instalasi Perangkap Hama dan tikus.

4. Melakukan kegiatan operasional dan perawatan instalasi alat.

5. Menerima pendampingan dan pembimbingan teknis dari tim pelaksana kegiatan dalam hal pembuatan, operasional dan perawatan instalasi alat.

\subsection{Evaluasi Pelaksanaan Program dan Kerberlanjutannya \\ Evaluasi kegiatan berbasis pada luaran} kegiatan dan harapan masyarakat terkait penyelesaian masalah yang dihadapi sebatas pada masalah prioritas yang disepakati. Evaluasi kegiatan berupa luaran berbentuk alat/mesin (10 set perangkap serangga, 10 set perangkap tikus, dan 2 unit mesin perontok padi) dievaluasi secara internal pada bulan Agustus 2019, sedangkan evaluasi pelaksanaan eksternal (Kemristekdikti) pada tanggal 4-5 Desember 2019. Untuk luaran terhadap kinerja alat dan mesin dievaluasi pada bulan September 2019.

Keberlanjutan pemanfaatan alat dan mesin dipastikan dapat dilaksanakan di tingkat petani/masyarakat karena alat dan mesin tersebut rutin dimanfaatkan oleh mereka serta telah terbentuk dan berjalannya organisasi/lembaga kelompok tani. Jadi tim pelaksana yakin akan keberlanjutan program ini diteruskan oleh masing-masing kelompok tani dan setelah selesai tahun anggaran akan berkoordinasi secara insidentil dengan tim pelaksana kegiatan PPTTG.

\section{KELUARAN YANG DICAPAI (OUTPUT)}

Keluaran (output) kegiatan antara target dan realisasi adalah sebagaimana tertera pada table berikut.

Tabel 2. Keluaran Kegiatan Target dan Realisasi

\begin{tabular}{|c|c|c|c|c|}
\hline $\begin{array}{l}\mathrm{N} \\
\mathrm{o}\end{array}$ & $\begin{array}{l}\text { Jenis } \\
\text { Luaran } \\
\text { (Output) }\end{array}$ & $\begin{array}{l}\text { Target } \\
\text { Outpu } \\
\mathrm{t}\end{array}$ & $\begin{array}{l}\text { Realisa } \\
\text { si } \\
\text { Output }\end{array}$ & Keterangan \\
\hline 1 & $\begin{array}{l}\text { Alat } \\
\text { perangk } \\
\text { ap tikus } \\
\text { pertania } \\
\text { n }\end{array}$ & 10 set & 10 set & $\begin{array}{l}\text { Sudah } \\
\text { pemasangan }\end{array}$ \\
\hline 2 & $\begin{array}{l}\text { Alat } \\
\text { perangk } \\
\text { ap } \\
\text { serangg } \\
\text { a } \\
\end{array}$ & 10 set & 10 set & $\begin{array}{l}\text { Termanfaatka } \\
\mathrm{n} \text { dan berdaya } \\
\text { guna }\end{array}$ \\
\hline 3 & $\begin{array}{l}\text { Mesin } \\
\text { peronto } \\
\text { k padi }\end{array}$ & 2 unit & 2 unit & $\begin{array}{l}\text { Termanfaatka } \\
\mathrm{n}\end{array}$ \\
\hline 4 & $\begin{array}{l}\text { Publikas } \\
\text { i di pada } \\
\text { jurnal } \\
\text { ber- } \\
\text { ISSN } \\
\text { DIPAM } \\
\text { AS }\end{array}$ & $\begin{array}{l}1 \\
\text { artikel }\end{array}$ & $\begin{array}{l}\text { Draft } \\
\text { artikel } \\
\text { submitt } \\
\text { ed }\end{array}$ & On proggress \\
\hline \multirow[t]{3}{*}{5} & \multirow{3}{*}{$\begin{array}{l}\text { Publikas } \\
\mathrm{i} \\
\text { kegiatan } \\
\text { pada } \\
\text { media } \\
\text { massa }\end{array}$} & $\begin{array}{l}\text { online } \\
1 \text { kali }\end{array}$ & 4 kali & \\
\hline & & $\begin{array}{l}\text { surat } \\
\text { kabar } \\
1 \text { kali }\end{array}$ & 2 kali & \\
\hline & & $\begin{array}{l}\text { CSM } \\
\text { TV } 1 \\
\text { kali }\end{array}$ & 1 kali & $\begin{array}{l}\text { Selesai } \\
\text { disiarkan dan } \\
\text { dibagikan di } \\
\text { www.youtube. } \\
\text { com }\end{array}$ \\
\hline
\end{tabular}

Video

https://www.youtube.com/watch?v=5GATR1a3G ZI dan https://youtu.be/2kKF4csRF_E

Publikasi Media Massa Online https://pontianak.tribunnews.com/2019/09/14/pol tesa-laksanakan-kegiatan-pelatihan-tanamanpangan-untuk-petani-desa-tebas-sungai https://pontianak.tribunnews.com/2019/09/14/pol tes-gelar-pelatihan-hamdi-sukses-perlupengetahuan-dan-keterampilan 


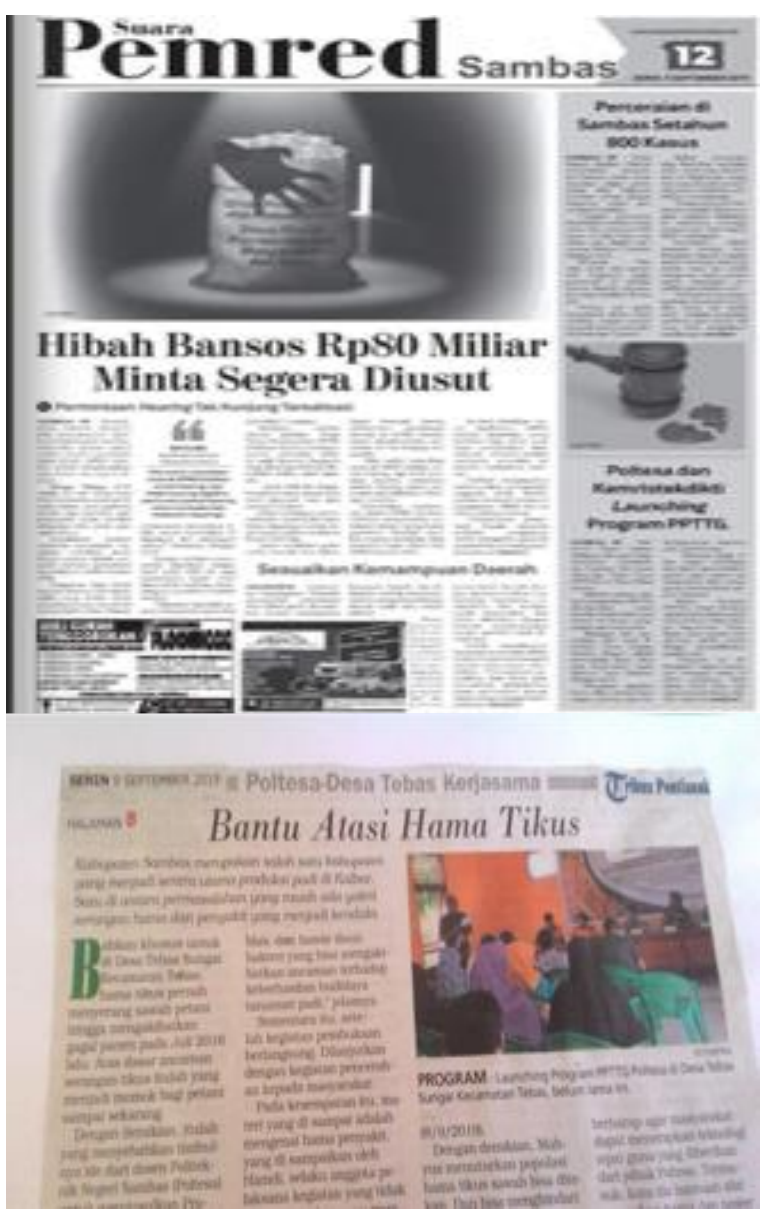

\section{MANFAAT YANG DIPEROLEH (OUTCOME)}

\subsection{Fungsi dan Manfaat Produk Teknologi}

Fungsi dan manfaat produk teknologi yang dihasilkan dari kegiatan PPTTG adalah sebagai berikut:

1. Perangkap/bubu tikus

Perangkap atau bubu tikus ini untuk bermanfaat untuk menyelesaikan masalahmasalah sebagaimana dijelaskan pada Bab 1 . Dengan melakukan pembuatan, pemasangan dan pengelolaan perangkap tikus pertanian yang disertai pula dengan pembekalan ilmu dan pengetahuan dalam pengelolaan usahatani secara baik diharapkan mampu mengendalikan serangan tikus sawah/pertanian dan mampu mencegah kehilangan hasil atau kegagalan panen.

2. Perangkap serangga (light trap)

Perangkap serangga ini berguna untuk mengenali potensi serangan serangga yang merupakan cikal bakal dari populasi yang bersifat merugikan bagi tanaman padi jika berkembang biak di atas ambang batas ekonomi usahatani padi. Pembekalan ilmu untuk mengenal dan mengendalikan hama dan penyakit secara komprehensif serta memanfaatkan perangkap serangga untuk tanaman padi dan tanaman lainnya di lahan yang dikelola oleh petani yang tergabung dalam 2 kelompok tani dalam luasan lahan 50 hektar tersebut dilakukan untuk efektivitas pemanfaatan alat yang diberikan yang merupakan teknologi ramah lingkungan.

3. Mesin perontok padi

Membuat dan menghibahkan mesin perontok padi kepada masyarakat ini berfungsi dan bermanfaat untuk mencegah rebutan/antrian panjang dan pertikaian dalam merebutkan mesin yang terjadi selama ini. Kegiatan ini pula bisa membekali mereka untuk menggunakan mesin dengan baik agar lebih awet dan tahan lama serta bisa memperbaikinya jika terjadi kerusakan ringan.

\subsection{Dampak Ekonomi dan Sosial}

Secara ekonomi, adanya penerapan teknologi melalui PPTTG akan mencegah kerugian dalam usahatani padi (akibat serangan tikus sawah), mengefektifkan pencegahan serangan hama (melalui perangkap hama/light trap), dan mengefisienkan biaya pasca panen padi (dengan alat perontok padi). Secara keseluruhan dampak ekonominya akan menyebabkan peningkatan pendapatan petani padi sawah sehingga diharapkan mampu mensejahterakan ekonomi masyarakat tani.

Secara sosial, dampak yang didapat dari penerapan teknologi adalah adanya ketenteraman di masyarakat karena adanya alat yang mencegah terjadinya kerugian dalam pengusahaan budidaya tanaman padi, serangan hama maupun penyakit yang dibawa oleh hama, dan tidak lagi terjadi rebutan antrian terhadap mesin perontok padi karena telah ada alat yang diberikan kepada kelompok. Ketenteraman di masyarakat adalah hal penting dalam politik pangan maupun kehidupan social masyarakat di negeri ini.

\subsection{Kontribusi Terhadap Sektor Lain}

Kontibusi kegiatan PPTTG tahun 2019 di Kecamatan Tebas begitu terasa bagi kemajuan di bidang pertanian tanaman pangan. Hal ini juga telah diungkapkan oleh penyuluh pertanian di Kecamatan Tebas. Bahwa selama ini pemerintah kabupaten melalui Dinas Pertanian dan Penyuluhan hanya mampu memberikan bantuan alat perangkap serangga sebagai 2 unit untuk seKecamatan Tebas, sedangkan bantuan dari program PPTTG bisa membantu sampai 10 unit untuk satu desa. 


\section{KENDALA/MANFAAT DAN TINDAK}

\section{LANJUT}

\subsection{Kendala/Hambatan}

Kendala-kendala yang dialami dalam kegiatan PPTTG ini antara lain adalah waktu panen yang telah lewat saat alat perangkap tikus diaplikasikan.

\subsection{Tindaklanjut}

Tindak lanjut dari kendala yang dihadapi agar bias diperbaiki adalah dengan tetap meneruskan aplikasi alat dengan melihat perkembangan efektivitasnya.

\section{KESIMPULAN DAN SARAN}

\subsection{Kesimpulan}

Penerapan teknologi tepat guna dirasakan benar-benar bermanfaat oleh masyarakat terutama anggota kelompok tani yang berusaha di bidang budidaya tanaman padi di Desa Tebas Sungai Kecamatan Tebas Kabupaten Sambas. Kegiatan ini telah menghasilkan pengendali tikus pertanian berupa alat perangkap tikus sebanyak 10 set, pengendali perangkap serangga (light trap) sebanyak unit unit yang terpasang permanen, mesin perontok padi sebanyak 2 unit untuk 2 kelompok tani yang juga diiringi dengan pelaksanaan pelatihan dan pendampingan yang terkait dengan penggunaan dan pemeliharaan alat/mesinnya.

\subsection{Saran}

Diharapkan program PPTTG dapat terus dilanjutkan baik untuk yang dilaksanakan oleh Politeknik Negeri Sambas maupun oleh perguruan tinggi lain baik di daerah Kabupaten Sambas maupun di daerah lain di Indonesia.

\section{DAFTAR PUSTAKA}

[BPS] Badan Pusat Statistik. 2018. Kabupaten Sambas Dalam Angka 2017. BPS. Sambas. 